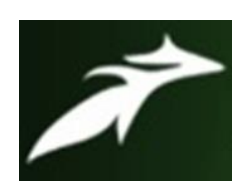

R.Gunasekar, International Journal of Advances in Agricultural Science and Technology,

Vol.8 Issue.2, February-2021, pg. 24-32

ISSN: 2348-1358

Impact Factor: 6.057

NAAS Rating: 3.77

\title{
Gene Action Studies on Yield and Its Attributes in Okra (Abelmoschus esculentus L.Moench)
}

\author{
R.Gunasekar \\ Asst.Professor and Head \\ Department of Vegetable Crops, Adhiparasakthi Horticultural College, Affiliated to Tamil Nadu Agricultural \\ University, Kalavai-632 506, Tamil Nadu, India \\ E mail:guna.genhort@gmail.com \\ DOI: 10.47856/ijaast.2021.v08i2.004
}

\begin{abstract}
Genetic studies assist the breeder in understanding the inheritance mechanism and enhance the efficiency of a breeding programme. In order to determine the mode of gene action involved in some economic traits of okra, two different crosses as started genetic materials were used for this purpose applying generation mean analysis. Significant differences for all studied traits for six populations $\mathrm{P}_{1}, \mathrm{P}_{2}, \mathrm{~F}_{1}, \mathrm{~F}_{2}, \mathrm{BC}_{1}$ and $\mathrm{BC}_{2}$ within each cross were found indicating the existence of genetic variation and possibility of selection for these traits. The crosses viz., MDU-1 X TCR 1173 and VRO 4 X TCR 2056 had complimentary type of epistasis along with significant additive gene effects and additive $\mathrm{x}$ additive interaction gene effects for most of the traits. Considering fruit yield per plant and its attributes, the two crosses were judged as the best cross for further selection programme. The presence of duplicate epistasis in the inheritance of traits including days to $50 \%$ flowering and fruit girth in both the crosses might be improved through recurrent selection in biparental progenies and may possible be overcome by delaying the selection to later generations otherwise, one or two cycle of intermating of segregating population may be usefull to improve the characters.
\end{abstract}

Keywords: Okra, gene action, epistasis, generation mean analysis. Six parameters, yield, yield attributes

\section{Introduction}

Okra (Abelmoschus esculentus L.Moench) is considered one of the most important vegetable crops in India having prominent position among short duration ones. Okra belongs to family Malvaceae with $2 \mathrm{n}=130$ chromosomes and amphidiploid nature. It is usually consumed for its green tender fruits as a vegetable in a variety of ways. The tender fruits are used as vegetable, eaten boiled or in culinary preparations as sliced and fried pieces. Its average nutritive value is higher than tomato, egg-plant and most of the cucurbits. It is an excellent source of iodine besides other minerals and vitamin. Nutritionally, okra green fruits are rich in vitamins (A, B and C) and minerals $(\mathrm{Ca}, \mathrm{P}, \mathrm{Mg}$ and $\mathrm{Fe}$ ). Its mature fruit and stems contain crude fibre, which is used in the paper industry. The roots and stem of okra are used as clarifier for cane juice from brown sugar or gur is prepared (Chuhan, 1972). It is grown throughout the tropical and sub-tropical regions as well as in the warmer parts of the temperate regions. In order to increase the yielding potential, it is important to utilize the available genetic potential efficiently. The nature and magnitude of genetic variation present in population is elucidated by genetic analysis of quantitative traits. Estimating the type of gene effects in plant population is essential to decide the type of breeding procedure to be followed

Success of any crop improvement programme is mainly dependent upon the information regarding nature and magnitude of gene effects controlling economic quantitative traits. The knowledge about nature and magnitude of fixable and non-fixable type of gene effects controlling quantitative yield traits is essential in order to achieve the genetic improvement in this crop. The information on the nature of the gene action could be helpful in 


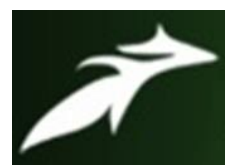

R.Gunasekar, International Journal of Advances in Agricultural Science and Technology,

Vol.8 Issue.2, February-2021, pg. 24-32

ISSN: 2348-1358

Impact Factor: 6.057

NAAS Rating: 3.77

predicting the effectiveness of selection in a segregating population. A distinct knowledge of the type of gene effect, its magnitude and composition of genetic variance are of fundamental important to a plant breeder. The efficient partitioning of genetic variance into its components viz., additive, dominance and epistasis helps in formulating an effective and sound breeding programme.

The presence or absence of epistasis can be detected by the analysis of generation means using the scaling test, which measures epistasis accurately, whether it is complimentary or duplicate at the digenic level. Two genetic models viz., Gamble (1962) and Hayman (1958) were simultaneously used for determining the nature of gene action involved in the inheritance of yield and yield contributing characters. The information regarding gene action involved in control of inheritance for yield and yield contributing characters through generation mean analysis is of immense use to the plant breeder to decide suitable breeding strategy for improvement of these characters. Several models for analysis of generation mean as was described by Hayman (1958) and have been developed. Parents $\left(\mathrm{P}_{1}\right.$ and $\left.\mathrm{P}_{2}\right), \mathrm{F}_{1}, \mathrm{~F}_{2}$ and first and second backcrosses $\left(\mathrm{BC}_{1}\right.$ and $\left.\mathrm{BC}_{2}\right)$ as six basic generations were used to propose estimating mean and variance of quantitative traits. Estimating additive, dominance and epistatic effects could be done using generation mean analysis as a quantitative genetic method (Mather and Jinks, 1982).

\section{Material and Methods}

The present investigation was carried out at Department of Vegetable Science, Adhiparasakthi Horticultural College, Kalavai, during the period of 2016 - 2017 and 2017-2018. Six basic sets of generations namely $\mathrm{P}_{1}, \mathrm{P}_{2}, \mathrm{~F}_{1}, \mathrm{~F}_{2}, \mathrm{BC}_{1}$ and $\mathrm{BC}_{2}$ were derived from two crosses involving four contrasting genotypes of okra. Two crosses involving four genetically diverse parents viz., MDU1, VRO 4, TCR 1173 and TCR 2056 were crossed in September, 2016 by hand emasculation and pollination. The crosses were referred as Cross I (MDU-1 X TCR 1173) and Cross II (VRO 4 X TCR 2056). In January, $2017 \mathrm{~F}_{1}$ seeds were sown to produce $\mathrm{F}_{2}$ seeds; subsequent flower buds were back crossed to produce the first backcross $\left(\mathrm{BC}_{1}\right)$ and second backcross $\left(\mathrm{BC}_{2}\right)$. The generations were analysed during summer 2017 in Randomized Block Design with randomization of generations within each cross in three replications. In each replication, observations were recorded on 5 random competitive plant of $\mathrm{P}_{1}, \mathrm{P}_{2}, \mathrm{~F}_{1}, 20$ plants on $\mathrm{F}_{2}$ and $\mathrm{BC}_{1}, \mathrm{BC}_{2}$ on 15 plants. The treatments showing significant differences for the traits were subjected to generation mean analysis and determination of gene effects using six parameter models as suggested by Hayman (1958). Chi-square test were calculated as per joint scaling test (Cavalli 1952). Presence of nonallelic gene interactions in all the crosses indicated in scaling test.

The observations were recorded on the nine quantitative characters namely days to $50 \%$ flowering, plant height $(\mathrm{cm})$, number of branches per plant, number of nodes per plant, number of fruits per plant, fruit length $(\mathrm{cm})$, fruit girth $(\mathrm{cm})$, fruit weight $(\mathrm{g})$ and fruit yield per plant $(\mathrm{g})$. Data were first tested for non-allelic interaction by individual scaling test A, B, C and D given by Mather (1949). Further analysis of data was performed according to the method of "Joint scaling test" given by Cavalli (1952). For computation of gene effects for yield and its components with six basic generations, Hayman's (1958) six parameter models were used. And also the significant value of chi square for this trait in all the crosses indicated that the three parameter model did not adequately explain the genetic variability for these traits. The inadequacy of the model was also indicated the presence of epistasis (non-allelic gene interaction), which was also inferred from the generation means. Duplicate type of interaction and complementary epistasis in two crosses estimated gene effects for different trait

2.1. Statistical and genetic analysis: Using GenStat software, analyses of variances were done for six populations (The two parents, $\mathrm{F}_{1}, \mathrm{~F}_{2}, \mathrm{BC}_{1}$ and $\mathrm{BC}_{2}$ ) within each cross with respect to all the 


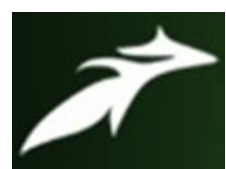

R.Gunasekar, International Journal of Advances in Agricultural Science and Technology,

Vol.8 Issue.2, February-2021, pg. 24-32

ISSN: 2348-1358

Impact Factor: 6.057

NAAS Rating: 3.77

traits. In addition, analysis of variance according to (RBD) for the traits was made to detect the significance of the observed differences among and within crosses (Singh and Narayanan, 2000).

The mode of inheritance of the okra yield components and yield was estimated for each cross combination by generation mean analysis ( $\mathrm{P} 1, \mathrm{P} 2, \mathrm{~F} 1, \mathrm{~F} 2, \mathrm{BC} 1$, and $\mathrm{BC} 2)$, using additive/dominance model, three parameter model (Mather \& Jinks 1982).

The effects of genes were calculated as:

a) $(\mathrm{m})=0.5 \mathrm{P} 1+0.5 \mathrm{P} 2+4 \mathrm{~F} 2-2 \mathrm{BC} 1-2 \mathrm{BC} 2$

$(\mathrm{d})=0.5 \mathrm{P} 1-0.5 \mathrm{P} 2$

$\mathrm{SE} 2(\mathrm{~d})=0.25 \mathrm{SE} 2 \mathrm{P} 1+0.25 \mathrm{SE} 2 \mathrm{P} 2$

(h) $=6 \mathrm{BC} 1+6 \mathrm{BC} 2-8 \mathrm{~F} 2-\mathrm{F} 1-1.5 \mathrm{P} 1-1.5 \mathrm{P} 2$

$\mathrm{SE} 2(\mathrm{~h})=36 \mathrm{SE} 2 \mathrm{BC} 1+36 \mathrm{SE} 2 \mathrm{BC} 2+64 \mathrm{SE} 2 \mathrm{~F} 2+\mathrm{SE} 2 \mathrm{~F} 1+2.25 \mathrm{SE} 2 \mathrm{P} 1+2.25 \mathrm{SE} 2 \mathrm{P} 2$

Where $(\mathrm{m})$ representing mean, $(\mathrm{d})$ additive and $(\mathrm{h})$ dominance effect.

The estimated $(\mathrm{m}),(\mathrm{d})$ and $(\mathrm{h})$ values were tested by t-test at the 0.05 and 0.01 levels of probability. The gene effects were calculated and tested by inversion of matrix system, on the basis of the expected model. The adequacy of the model was tested according to individual scaling and joint chi square tests. Individual scaling tests were based on mean generation values for six generations ( $\mathrm{P} 1, \mathrm{P} 2, \mathrm{~F} 1, \mathrm{~F} 2, \mathrm{BC} 1$, and $\mathrm{BC} 2)$ :

b) $\mathrm{A}=2 \mathrm{BC} 1-\mathrm{P} 1-\mathrm{F} 1$

$\mathrm{SE} 2(\mathrm{~A})=4 \mathrm{SE} 2 \mathrm{BC} 1+\mathrm{SE} 2 \mathrm{P} 1+\mathrm{SE} 2 \mathrm{~F} 1$

$\mathrm{B}=2 \mathrm{BC} 2-\mathrm{P} 2-\mathrm{F} 1$

$\mathrm{SE} 2(\mathrm{~B})=4 \mathrm{SE} 2 \mathrm{BC} 2+\mathrm{SE} 2 \mathrm{P} 2+\mathrm{SE} 2 \mathrm{~F} 1$

$\mathrm{C}=4 \mathrm{~F} 2-2 \mathrm{~F} 1-\mathrm{P} 1-\mathrm{P} 2$

$\mathrm{SE} 2(\mathrm{C})=16 \mathrm{SE} 2 \mathrm{~F} 2+4 \mathrm{SE} 2 \mathrm{~F} 1+\mathrm{SE} 2 \mathrm{P} 1+\mathrm{SE} 2 \mathrm{P} 2$

The joint chi square test was based on comparison of experimental mean generation values and the expected generation values that indicate epistatic effects. If at least one value from the C, A, B set and the calculated chi square turn out statistically significant, three parameter model is declared inadequate and the effects of epistasis were calculated using six parameter model:

C) $(\mathrm{i})=2 \mathrm{BC} 1+2 \mathrm{BC} 2-4 \mathrm{~F} 2$

$\mathrm{SE} 2(\mathrm{i})=4 \mathrm{SE} 2 \mathrm{BC} 1+4 \mathrm{SE} 2 \mathrm{BC} 2+16 \mathrm{SE} 2 \mathrm{~F} 2$

(j) $=2 \mathrm{BC} 1-\mathrm{P} 1-2 \mathrm{BC} 2+\mathrm{P} 2$

$\mathrm{SE} 2(\mathrm{j})=4 \mathrm{SE} 2 \mathrm{BC} 1+\mathrm{SE} 2 \mathrm{P} 1+4 \mathrm{SE} 2 \mathrm{BC} 2+\mathrm{SE} 2 \mathrm{P} 1$

(l) $=\mathrm{P} 1+\mathrm{P} 2+2 \mathrm{~F} 1+4 \mathrm{~F} 2-4 \mathrm{BC} 1-4 \mathrm{BC} 2$

SE2 (1) = SE2P1 + SE2P2 + 4SE2F1 + 16SE2F2 + 16SE2BC1 + 16SE2BC2;

Where (i) represents additive $\mathrm{x}$ additive, (j) additive $\mathrm{x}$ dominance and (l) dominance $\mathrm{x}$ dominance effects.

\section{Results and Discussion}

Breeding method for any crop improvement programme is largely depends on the nature of gene action prevailed. Study of gene effects controlling different characters is therefore, a pre-requisite for launching a systematic and meaningful crop improvement programme. Quantitative characters which are of great interest, are governed by large number of genes having their own effects. These are too modified by several environmental factors. Thus, analysis at the level of individual genes become impractical and whole genome analysis over the totality of the gene should be undertaken (Wright, 1956). The genetic variability, thus, should be partitioned into its broad components. 


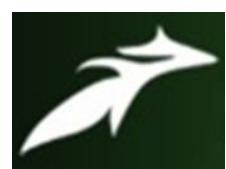

R.Gunasekar, International Journal of Advances in Agricultural Science and Technology,

Vol.8 Issue.2, February-2021, pg. 24-32

ISSN: 2348-1358

Impact Factor: 6.057

NAAS Rating: 3.77

Most valuable genetic analysis of quantitative characters can be said to have initiated with the work of Fisher (1918). He showed that these character measure continuous variation and fallow the Mendelian laws. He partitioned hereditary variance into three components, (i) an additive portion resulting from average effects of gene, (ii) a portion resulting from dominance effects (intra allelic interaction) of genes, and (iii) a portion resulting from epistatic effects (non-allelic interaction) of genes.

Hayman and Mather (1955) described the digenic interactions in continuous variation. Such partitioning of variation into its components requires growing a large number of related generations under an appropriate design. Hayman (1958) developed independently the method of estimation of six genetic parameters using generation means. These model are based on certain assumptions such as (i) diploid inheritance,( ii) multiple allelism is absent, (iii) linkage is absent, (iv) absence of lethal genes, (v) constant variability for all genotypes and (vi) environmental effects are additive with the genotypic value.

In crops like okra, only additive component of genetic variation can be utilized. Among the interaction effect additive $\mathrm{x}$ additive type of interaction effect are more useful for the breeders. Complementary epistasis can also be successful exploited in the selection programme.

The present study was planned to estimate the nature and magnitude of allelic and non-allelic interactions in okra. The six generation of each of these crosses were grown and observation were recorded on nine important characters. The discussions on the result obtained with regard to nature of gene action are reported here character wise for all the traits in two crosses.

The result of scaling tests viz., A, B, C and D (Table 1) revealed significant values indicated the presence of appreciable amount of epistasis for all the traits studied. Presence of epistatic gene action for yield and its attributes have been reported by Mistry (2013), Jogi et al. (2018) and Kalyani et al. (2021). The chi square ( $\mathrm{x}^{2}$ ) values were significant according to joint scaling test for all the characters in the two crosses indicated that the three parameter model did not adequately explain the genetic variability for the traits studied. Therefore, a six parameter model was applied to accommodate epistatic interactions. The result showed that epistatic gene interactions of six parameter model of generation mean analysis was presented in table. 2

\subsection{Days to $50 \%$ flowering}

The genetic parameter of additive, additive $\mathrm{x}$ additive and dominance $\mathrm{x}$ dominance were highly significant in the cross MDU-1 x TCR 1173 indicated the importance of both additive and dominance gene effect in the inheritance of the trait. The magnitude of additive and additive $\mathrm{x}$ additive gene effects were found to contribute substantially in the inheritance of days to 50\% flowering. This is with the agreement of Reddy et al. (2013). In the cross VRO 4 x TCR 2056, additive component was positive but not significant whereas the parameter additive $\mathrm{x}$ additive was positively significant. The magnitude of dominance was higher and positive than additive $\mathrm{x}$ additive. However, the negative gene effect of dominance $\mathrm{x}$ dominance diminished the dominant alleles. Moreover, the opposite sign of (h) and (l), showed the presence of duplicate type of epistasis in both the crosses.

\subsection{Plant height}

Additive and additive $\mathrm{x}$ additive gene actions were highly significant and positive for this trait in the cross MDU-1 x TCR 1173, whereas, dominance gene action was significant and positive indicated the dominance gene effect for plant height. However, the genetic parameter namely dominance $\mathrm{x}$ dominance was negatively significant showed the diminishing effect of this parameter and indicated the important role of dominance gene action for dwarf plant. Opposite sign of (h) and (l) showed the presence of duplicate type of epistasis. This was in accordance with the findings of Arora et al. (2010). 


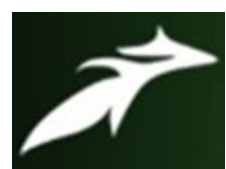

R.Gunasekar, International Journal of Advances in Agricultural Science and Technology,

Vol.8 Issue.2, February-2021, pg. 24-32

ISSN: 2348-1358

Impact Factor: 6.057

NAAS Rating: 3.77

\subsection{Number of branches per plant}

The cross MDU-1 x TCR 1173 had highly significant genetic effects of additive, additive $\mathrm{x}$ additive and dominance components indicated that both additive and non-additive gene actions were important for this trait. The magnitude of additive variance was higher than dominance gene effect showing preponderance of additive gene action and it is fixable in both the crosses. The opposite sign of (h) and (l) in the cross MDU-1 x TCR 1173 and same sign of (h) and (l) in the cross VRO 4 x TCR 2056 revealed duplicate and complementary types of epistasis respectively. Similar findings were reported by Mistry et al. (2013) and Jogi et al. (2018).

\subsection{Number of nodes per plant}

The parameter viz., additive and additive $\mathrm{x}$ additive were highly significant for this trait and indicated the importance of these gene action in the inherent of this trait in the cross MDU-1 x TCR 1173. Whereas in the cross VRO 4 x TCR 2056, all the parameter were highly significant except additive gene action which showed the preponderance of non-additive gene action governing this trait. The same sign of $(\mathrm{h})$ and (l) in both the crosses indicated the presence of complementary type of epistasis. This is in line with the findings of Verma et al. (2015).

\subsection{Number of fruits per plant}

Among the estimates from generation mean analysis, additive gene action was significant for this trait in the cross MDU-1 x TCR 1173. However, dominance and dominance $\mathrm{x}$ dominance interaction were higher than other parameter indicated that this character was governed by non-additive gene action. The magnitude of additive and additive $\mathrm{x}$ additive gene action were higher than other genetic components showed the predominance of additive gene action and the importance of additive gene action in the inheritance of the trait in the cross VRO 4 x TCR 2056. Same sign of (h) and (l) in both the crosses showed the presence of complementary type of epistasis. This result is in accordance with the findings of Arora et al. (2010).

\subsection{Fruit length (cm)}

The estimates of dominance and dominance $\mathrm{x}$ dominance were highly significant in both the crosses indicated the importance of non-additive gene action for this trait. Both the crosses had same sign for (h) and (l) indicated the prevalence of complementary type of epistasis. Similar report was also given by Patel et al., (2010)

\subsection{Fruit girth (cm)}

The cross MDU-1 x TCR 1173 had the components of non-significant and positive additive gene action, significant additive $\mathrm{x}$ additive gene action and dominance gene action indicated the importance of additive and dominance gene effects. Whereas the cross VRO 4 x TCR 2056 had significant additive and additive $\mathrm{x}$ additive gene action for this trait. Opposite. The sign of (h) and (l) of the two crosses indicated the presence of duplicate type of epistasis. Similar findings were reported by Mistry et al. (2013)

\subsection{Fruit weight (g)}

The parameter viz., dominance, dominance $\mathrm{x}$ dominance were highly significant and higher than additive gene action in the cross MDU-1 x TCR 1173 revealed the importance of non-additive gene action for this trait. On the other hand, the cross VRO 4 x TCR 2056 had significant additive gene action indicated the predominance of additive variance for this trait. Both the crosses had same sign for (h) and (l) indicated the presence of complimentary type of epistasis. This is in accordance with the findings of Soher et al. (2013).

\subsection{Total fruit weight per plant (g)}

Among the genetic parameters, the gene effects additive, additive $\mathrm{x}$ additive were higher and significant than dominance variance indicated the preponderance of additive gene action for this trait in the cross MDU- $1 \mathrm{x}$ TCR 1173. All the genetic parameters except additive $\mathrm{x}$ additive gene action were higher and significant in the cross VRO 4 x TCR 2056. The higher magnitude of dominance variance indicated the dominant alleles action for this trait. Same sign of (h) and (l) in the both crosses indicated the presence of complimentary epistasis. Similar findings were reported by Soher et al. (2013) and Kalyani et al. (2021). 


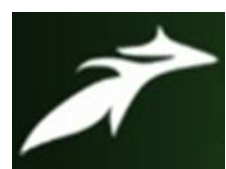

R.Gunasekar, International Journal of Advances in Agricultural Science and Technology,

Vol.8 Issue.2, February-2021, pg. 24-32

ISSN: 2348-1358

Impact Factor: 6.057

NAAS Rating: 3.77

In general, Additive and Additive $\mathrm{x}$ Additive genetic variance is a pre-requisite for genetic gain under selection, because this is the only genetic variance which responds to selection and it can be fixed in homozygous cultivars in crops like okra. While the variation due to dominance effects and their interactions cannot be exploited effectively.

The phenomenon of duplicate epistasis is unfavourable from the breeder's point of view because of its decreasing effect on the analysed trait (Zdravkovic et al. 2000). The presence of duplicate epistasis would be detrimental for rapid progress, making it difficult to fix genotypes with increased level of character manifestation because the positive effects of one parameter would be cancelled out by the negative effect of another whereas complementary type of epistasis is favourable effect in breeding programme.

\section{Conclusion}

In the present investigation, both additive and non-additive gene effects were important in the genetic control of yield per plant and its component under study. The characters governed by additive gene effects and additive $\mathrm{x}$ additive gene interaction effects are fixable. The crosses which are governed by complementary epistasis where sign of dominance gene effects and dominance $\mathrm{x}$ dominance gene interaction effects are similar are also worth for exploitation. Such crosses have the potentiality to produce transgressive segregants on the positive side. Pedigree method of breeding followed by simple selection in later segregating generations will be a meaningful breeding strategy to be followed in such crosses for the improvement of the characters under consideration. On the other hand, the prevalence of duplicate epistasis in the inheritance of traits including days to $50 \%$ flowering and fruit girth in both the crosses and the traits plant height and number of branches per plant in the cross MDU-1 x TCR 1173 alone might be improved through recurrent selection in biparental progenies that would help in exploiting the duplicate type of non-allelic interaction and allow recombination and concentration of gene having cumulative effects in population as this method is helpful in breaking up undesirable linkage case of duplicate type of epistasis, selection in the early segregating generations may not yield desirable recombinants. This may possible be overcome by delaying the selection to later generations otherwise, one or two cycle of intermating of segregating population may be useful to improve the characters.

\section{References}

[1]. Arora, D., Jindal, S. K. and Ghai, T.R. 2007.Generation mean analysis for earliness related traits in okra (Abelmoschusesculentus L. Moench). J. Genet. and Breed., 61:1-7

[2]. Cavalli, L.L. (1952). An Analysis of Linkage in Quantitative Inheritance. Lieve, E.C.R. and C.H. Waddington, (Eds.), HMSD, London, pp. 135-144

[3]. Chauhan, D.V.S. 1972. Vegetable production in India. Ram Prasad and Sons, Agra.

[4]. Fisher, R.A. (1918). The genetic theory of natural selection. Oxford Dever Pub., New York.

[5]. Hayman, B.I. and Mather, K. (1955). The description of genetic interactions in continuous variation. Biometrics, 11: 69-82.

[6]. Hayman, B.I. 1958. The separation of epistasis from additive and dominance variation in generation means. Heredity, 12: 371-390.

[7]. Jogi, S.R., Toprope V.N and N.R. Thakur. 2018. Generation mean analysis in okra (Abelmoschus esculentus (1.) Moench), Multilogic in Science, pp: 39-45

[8]. Kalyani D, S, Vishwanath and Jadhay.D. 2021, Generation mean analysis in okra (Abelmoschus esculentus L. Moench) for yield and yield contributing characters, The Pharma Innovation Journal; 10(1): 288-291

[9]. Mather, K. and J.L. Jinks, 1982. Biometrical Genetics. 3rd Edn., Chapman and Hall, London, Pages: $380-396$.

[10].Mistry, P.M., and Vashi, P.S. 2011.Genetics of pod yield and yield contributing characters in okra [Abelmoschusesculentus(L).Moench].Internat. J. of Plant Sci., 6(2): 298-303.

[11].Patel, K.D., Barad,A.V., Savaliya, J.J. and Butani, A.M. 2010. Generation mean analysis for fruit yield and its attributing traits in okra [Abelmoschusesculentus (L.)Moench].The Asian J. of Hort.,5(2): 256-259. 


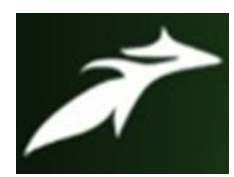

R.Gunasekar, International Journal of Advances in Agricultural Science and Technology,

Vol.8 Issue.2, February-2021, pg. 24-32

ISSN: 2348-1358

Impact Factor: 6.057

NAAS Rating: 3.77

[12]. Reddy, M.A., Sridevi, O., Salimath, P.M. and Nadaf, H.L. 2013.Combining ability for yield and yield components through diallel analysis in okra (Abelmoschusesculentus(L.) moench). IOSR J. of Agric. and Veterinary Sci., 5 (2):01-06.

[13].Singh, P. and S.S. Narayanan, 2000. Biometrical Techniques in Plant Breeding. Kalyani Publishers, New Delhi, India, pp: 17-36.

[14]. Soher E.A. El-Gendy and M.H. Abd El-Aziz, 2013. Generation Mean Analysis of Some Economic Traits in Okra (Abelmoschus esculentus L. Moench). Journal of Applied Sciences, 13: 810-818.

[15]. Verma, A. and Sood, S. 2015. Gene action studies on yield and quality traits in okra (Abelmoschusesculentus (L.)Moench).Veg.Sci.,10(43):4006-4009

[16].Wright, S. (1956). Modes of selection. Amer. Nat., 90: 524.

[17].Zdravkovic, J., z.Markovic, M.Mijatovic, 2000. Epistatic gene effects on the yield of the parents of F1, F2, BC1 and BC2 progeny in tomato. Acta Physiol. Plant., 22: 261-265.

Table 1.Scaling test and joint scaling test for two crosses of okra for nine characters in okra

\begin{tabular}{|c|c|c|c|c|c|}
\hline $\begin{array}{c}\text { Crosses and } \\
\text { characters }\end{array}$ & $\mathbf{A}$ & B & $\mathrm{C}$ & D & $\mathbf{X}^{2}$ values \\
\hline \multicolumn{6}{|c|}{ Days to $50 \%$ flowering } \\
\hline $\begin{array}{c}\text { MDU-1x TCR } \\
1173\end{array}$ & $7.10 * * \pm 0.7$ & $4.15 \pm 0.61$ & $2.52^{* * *} \pm 0.11$ & $-4.50 * * \pm 0.30$ & $\mathbf{S}$ \\
\hline VRO 4x TCR 2056 & $-3.50 * * \pm 0.70$ & $2.00 * \pm 0.48$ & $0.80 \pm 0.68$ & $-3.00 * * \pm 0.46$ & $\mathbf{S}$ \\
\hline \multicolumn{6}{|c|}{ Plant height (cm) } \\
\hline $\begin{array}{c}\text { MDU-1x TCR } \\
1173\end{array}$ & $1.92 \pm 0.930$ & $-0.40 \pm 1.89$ & $-69.24 * * \pm 3.00$ & $-42.82 * * \pm 2.13$ & $\mathbf{S}$ \\
\hline VRO 4x TCR 2056 & $-12.70 * * \pm 3.61$ & $-12.90 \pm 11.43$ & $-4.92 \pm 2.46$ & $13.34 \pm 5.79$ & $\mathbf{S}$ \\
\hline \multicolumn{6}{|c|}{ No.of branches per plant } \\
\hline $\begin{array}{c}\text { MDU-1x TCR } \\
1173\end{array}$ & $0.77 * * \pm 0.21$ & $3.37 * * \pm 0.09$ & $2.18 \pm 0.10$ & $-2.38 * * \pm 0.05$ & $\mathbf{S}$ \\
\hline VRO 4x TCR 2056 & $0.05 \pm 0.05$ & $0.70^{* *} \pm 0.07$ & $-0.87 * * \pm 0.09$ & $0.22 * * \pm 0.0$ & $\mathbf{S}$ \\
\hline \multicolumn{6}{|c|}{ N0.of nodes per plant } \\
\hline $\begin{array}{c}\text { MDU-1x TCR } \\
1173\end{array}$ & $-0.40 \pm 0.78$ & $3.10 * * \pm 0.35$ & $6.34 * * \pm 0.89$ & $-1.52 * * \pm 0.39$ & $\mathbf{S}$ \\
\hline VRO 4x TCR 2056 & $2.25 * * \pm 0.40$ & $1.90 * * \pm 0.30$ & $2.50 * \pm 0.90$ & $2.05^{* * \pm 0.17}$ & $\mathbf{S}$ \\
\hline \multicolumn{6}{|c|}{ No.of fruits per plant } \\
\hline $\begin{array}{c}\text { MDU-1x TCR } \\
1173 \\
\end{array}$ & $-4.88 * * \pm 0.01$ & $-0.40 \pm 0.24-$ & $-.29 * * \pm 0.25$ & $-7.10 * * \pm 0.01$ & $\mathbf{S}$ \\
\hline VRO 4x TCR 2056 & $0.33 \pm 0.14$ & $-5.01 * * \pm 0.21$ & $5.86^{* *} \pm 0.52$ & $0.83 \pm 0.12$ & $\mathbf{S}$ \\
\hline \multicolumn{6}{|c|}{ Fruit length $(\mathrm{cm})$} \\
\hline $\begin{array}{c}\text { MDU-1x TCR } \\
1173\end{array}$ & $-4.42 * * \pm 0.35$ & $2.34 * * \pm 0.21$ & $-6.72 * * \pm 0.40$ & $0.06 \pm 0.03$ & $\mathbf{S}$ \\
\hline VRO 4x TCR 2056 & $-3.13 * * \pm 0.13$ & $-1.87 * * \pm 0.29$ & $-6.10 * * \pm 0.64$ & $1.70 * * \pm 0.15$ & $\mathbf{S}$ \\
\hline \multicolumn{6}{|c|}{ Fruit girth $(\mathbf{c m})$} \\
\hline $\begin{array}{c}\text { MDU-1x TCR } \\
1173 \\
\end{array}$ & $1.84 * * \pm 0.02$ & $1.39 * \pm 0.03$ & $0.80 * * \pm 0.03$ & $-1.27 * * \pm 0.00$ & $\mathbf{S}$ \\
\hline
\end{tabular}




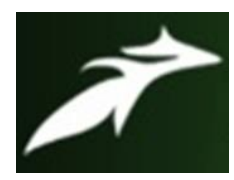

R.Gunasekar, International Journal of Advances in Agricultural Science and Technology,

Vol.8 Issue.2, February-2021, pg. 24-32

ISSN: 2348-1358

Impact Factor: 6.057

NAAS Rating: 3.77

\begin{tabular}{|c|c|c|c|c|c|}
\hline VRO 4x TCR 2056 & $1.64^{*} \pm 0.54$ & $3.72^{* *} \pm 0.42$ & $-4.48^{*} \pm 2.92$ & $2.14^{* *} \pm 0.08$ & S \\
\hline \multicolumn{7}{|c|}{ Fruit weight $(\mathbf{g})$} \\
\hline $\begin{array}{c}\text { MDU-1x TCR } \\
\text { 1173 }\end{array}$ & $-4.94^{* *} \pm 036$ & $-2.94^{* *} \pm 0.85$ & $-7.91^{* *} \pm 1.16$ & $-0.21 \pm 0.03$ & S \\
\hline VRO 4x TCR 2056 & $-4.50^{* *} \pm 0.24$ & $-4.81^{* *} \pm 1.21$ & $-6.80^{* *} \pm 1.27$ & $1.16^{* *} \pm 0.05$ & S \\
\hline \multicolumn{7}{|c|}{ Total fruit yield per plant (g) } \\
\hline $\begin{array}{c}\text { MDU-1x TCR } \\
\text { 1173 }\end{array}$ & $\begin{array}{c}139.51^{* *} \pm 29 . \\
64\end{array}$ & $309.64^{* *} \pm 16.77$ & $391.26^{* *} \pm 17.04$ & $\begin{array}{c}- \\
85.57^{* *} \pm 12.2 \\
4\end{array}$ & S \\
\hline VRO 4x TCR 2056 & $94.74^{* *} \pm 12.3$ & $182.37^{* *} \pm 17.64$ & $68.31^{* *} \pm 19.20$ & $163.21^{* *} \pm 8.0$ & 4 \\
\hline
\end{tabular}

Table 2. Estimates of gene effects

\begin{tabular}{|c|c|c|c|c|c|c|c|}
\hline $\begin{array}{c}\text { Crosses } \\
\text { and } \\
\text { characters }\end{array}$ & $\mathbf{m}$ & d & h & $\mathbf{i}$ & $\mathbf{j}$ & l & $\begin{array}{c}\text { Type of } \\
\text { epistasis }\end{array}$ \\
\hline & \multicolumn{6}{|c|}{ Days to $50 \%$ flowering } & \\
\hline $\begin{array}{c}\text { MDU-1x } \\
\text { TCR 1173 }\end{array}$ & $\begin{array}{c}51.00 * * \pm 0.0 \\
0\end{array}$ & $2.20 * * \pm 0.39$ & $-8.25 * * \pm 0.67$ & $\begin{array}{c}8.50 * * \pm 0.6 \\
6\end{array}$ & $1.25 * * \pm 0.30$ & $\begin{array}{c}16.50^{* *} \pm 1 \\
24\end{array}$ & Duplicate \\
\hline \multirow[t]{2}{*}{$\begin{array}{c}\text { VRO 4x } \\
\text { TCR 2056 }\end{array}$} & $\begin{array}{c}52.00 * * \pm 0.0 \\
0\end{array}$ & $0.11 \pm 0.41$ & $5.85 * * \pm 0.90$ & $\begin{array}{c}4.30 * * \pm 0.5 \\
2\end{array}$ & $0.95 \pm 0.30$ & $\begin{array}{c}- \\
8.50^{* * \pm 1.1} \\
8 \\
\end{array}$ & Duplicate \\
\hline & \multicolumn{6}{|c|}{ Plant height (cm) } & \\
\hline $\begin{array}{c}\text { MDU-1x } \\
\text { TCR 1173 }\end{array}$ & $\begin{array}{c}119.84^{* *} \pm 0 . \\
98\end{array}$ & $21.30 \pm 0.90$ & $98.58 * * \pm 4.32$ & $\begin{array}{c}90.64 * * \pm 4 \\
67\end{array}$ & $0.20 \pm 0.90$ & $\begin{array}{c}- \\
89.07^{* *} \pm 6 . \\
54\end{array}$ & Duplicate \\
\hline \multirow[t]{2}{*}{$\begin{array}{c}\text { VRO 4x } \\
\text { TCR 2056 } \\
\end{array}$} & $\begin{array}{c}120.97 * * \pm 0 . \\
25\end{array}$ & $-5.60 \pm 5.99$ & $18.68 \pm 11.88$ & $\begin{array}{c}21.68 \pm 11.9 \\
3 \\
\end{array}$ & $0.15 \pm 5.91$ & $\begin{array}{c}44.28 \pm 24.7 \\
0 \\
\end{array}$ & Complementary \\
\hline & \multicolumn{6}{|c|}{ No.of branches per plant } & \\
\hline $\begin{array}{c}\text { MDU-1x } \\
\text { TCR 1173 }\end{array}$ & $\begin{array}{c}2.91 * * \pm 0.00 \\
2\end{array}$ & $0.20^{* *} \pm 0.04$ & $0.37 * * \pm 0.17$ & $\begin{array}{c}0.34 * * \pm 0.0 \\
7\end{array}$ & $\begin{array}{c}- \\
0.33^{* * \pm 0.04} \\
8 \\
\end{array}$ & $-0.39 \pm 0.25$ & Duplicate \\
\hline \multirow[t]{2}{*}{$\begin{array}{c}\text { VRO 4x } \\
\text { TCR 2056 } \\
\end{array}$} & $3.81 * * \pm 0.01$ & $0.40 * * \pm 0.05$ & $2.89 * * \pm 0.21$ & $\begin{array}{c}2.96 * * \pm 0.2 \\
1\end{array}$ & $0.90 * * \pm 0.09$ & $\begin{array}{c}5.30 * * \pm 0.5 \\
1 \\
\end{array}$ & Complementary \\
\hline & \multicolumn{6}{|c|}{ N0.of nodes per plant } & \\
\hline $\begin{array}{c}\text { MDU-1x } \\
\text { TCR 1173 }\end{array}$ & $\begin{array}{c}13.64 * * \pm 0.0 \\
9 \\
\end{array}$ & $4.90 * * \pm 0.28$ & $5.03 * * \pm 0.81$ & $\begin{array}{c}2.64 * * \pm 0.7 \\
8\end{array}$ & $-0.95 * \pm 0.45$ & $1.34 \pm 0.37$ & Complementary \\
\hline \multirow[t]{2}{*}{$\begin{array}{c}\text { VRO 4x } \\
\text { TCR 2056 }\end{array}$} & $\begin{array}{c}15.32 * * \pm 01 \\
7\end{array}$ & $\begin{array}{c}- \\
1.70 * * \pm 0.09\end{array}$ & $1.90 * * \pm 0.73$ & $\begin{array}{c}2.40 * * \pm 0.4 \\
1 \\
\end{array}$ & $1.60 * * \pm 0.05$ & $\begin{array}{c}2.90 * * \pm 08 \\
8\end{array}$ & Complementary \\
\hline & \multicolumn{6}{|c|}{ No.of fruits per plant } & \\
\hline $\begin{array}{c}\text { MDU-1x } \\
\text { TCR 1173 } \\
\end{array}$ & $\begin{array}{c}15.94 * * \pm \\
0.09\end{array}$ & $\begin{array}{c}3.43 * * \pm \\
0.16\end{array}$ & $5.90 * * \pm 0.49$ & $\begin{array}{c}-0.49 \pm \\
0.25 \\
\end{array}$ & $0.31 \pm 0.21$ & $\begin{array}{c}6.93 * * \pm \\
0.97 \\
\end{array}$ & Complementary \\
\hline \multirow[t]{2}{*}{$\begin{array}{c}\text { VRO 4x } \\
\text { TCR } 2056 \\
\end{array}$} & $\begin{array}{c}14.99 * * \pm \\
0.08\end{array}$ & $0.69 * \pm 0.39$ & $6.61 * * \pm 0.69$ & $\begin{array}{c}43.41 * * \pm \\
0.83 \\
\end{array}$ & $\begin{array}{c}0.92 * * \pm \\
0.44\end{array}$ & $3.11 \pm 1.08$ & Complementary \\
\hline & \multicolumn{6}{|c|}{ Fruit length $(\mathbf{c m})$} & \\
\hline MDU-1x & $10.43 * * \pm$ & $-0.12 \pm 0.20$ & $8.96 * * \pm 0.44$ & $4.36 * * \pm$ & $-0.63 \pm 0.55$ & $3.18 * * \pm$ & Complementary \\
\hline
\end{tabular}




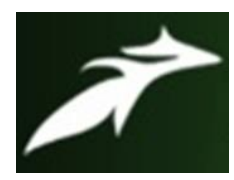

R.Gunasekar, International Journal of Advances in Agricultural Science and Technology,

Vol.8 Issue.2, February-2021, pg. 24-32

ISSN: 2348-1358

Impact Factor: 6.057

NAAS Rating: 3.77

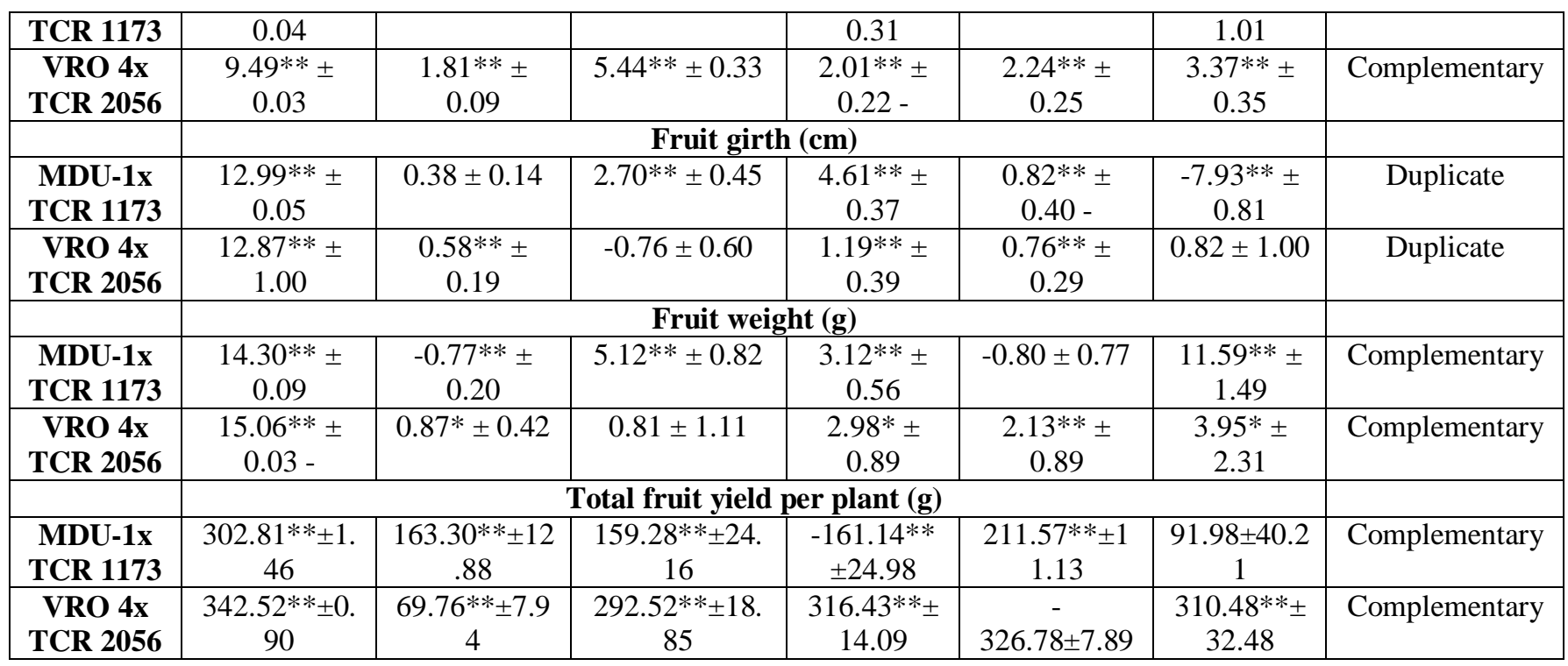

